\title{
EXPERIMENTS ON THE RELATION OF CREATININE AND UREA CLEARANCE TESTS OF KIDNEY FUNCTION AND THE NUMBER OF GLOMERULI IN THE HUMAN KIDNEY OBTAINED AT AUTOPSY
}

\author{
By J. M. HAYMAN, JR., AND S. M. JOHNSTON
}

(From the H. K. Cushing Laboratory of Experimental Medicine in the Department of Medicine of Western Reserve University and the Medical Service of Lakeside Hospital, Cleveland)

(Received for publication May 1, 1933)

Correlation of the results of tests of renal function with the pathological changes in the kidney has proved extremely difficult. To cite a simple example, in the marked proteinuria of degenerative Bright's disease, lesions of the glomeruli may be either slight or undiscoverable, while the tubule cells are strikingly abnormal. And yet, by far the greatest part of the protein is believed to have been excreted through the glomeruli. Similar difficulties have led many students to the conclusion that alterations of kidney function are independent of the nature of the anatomical changes in the kidney. Fortunately for the clinician, the results of kidney function tests can be expressed in relation to the normal, without regard to the nature or the anatomical site of the condition which has produced the abnormality. The average amount of urea excreted per minute by a normal individual with high urine volumes is equal to the urea contained in $75 \mathrm{cc}$. of blood (1). If it is only equivalent to that contained in $20 \mathrm{cc}$. of blood, kidney function may be said to be reduced without any intimation whether this reduction is brought about by diminished blood flow, decrease in the amount of renal tissue, increased reabsorption of urea by the tubules or diminished secretion. But an attempt to discover the mechanism of such reductions in function is irresistible to one concerned with the study of kidney disease.

Van Slyke and his collaborators (2), from a comparison of "terminal" urea clearance values and autopsy findings, suggested that in hemorrhagic and degenerative Bright's disease one may interpret the blood urea clearance as a measure of the proportion of glomerular tissue still functioning, while in arteriolar. sclerosis it appeared proportional to the decrease in renal blood flow rather than to the glomerular destruction. Addis (3) used the ratio (urea in 1 hour's urine/blood urea concentration) (which under his conditions can be converted into maximum urea clearance by multiplying by 1.67), as a measure of the extent of the renal lesion-" the amount 
of renal tissue which has been rendered functionless by the disease process." He did not attempt to distinguish between actual decrease in mass of tissue present and decreased accomplishment of a normal kidney mass. Thus should the ratio be reduced, let us say half normal, by removal of one kidney or by poisoning both kidneys, even by a poison from which recovery could take place, the two results would be considered the same-in each half the renal tissue had ceased to work.

Decrease in the creatinine clearance test has usually been ascribed to decrease in the volume of glomerular filtrate (4). Such a reduction could be due to decrease in blood flow, blood pressure or filtering surface. On the other hand, if the tubule cells were so damaged that they were unable to resist back diffusion of creatinine filtered through the glomeruli, or to secrete the constant fraction of the amount filtered as Shannon, Jolliffe and Smith believe (5), there might be a reduction in creatinine clearance without any decrease in the amount of glomerular filtrate. In such circumstance, it seems difficult to relate the decrease directly to reduction in functioning mass of renal tissue.

In the hope of furthering a physiological interpretation of the creatinine and urea clearance tests, we have estimated the number of glomeruli in one kidney of a number of patients whose clearances had been measured from one day to several months before death. All of the patients had systolic blood pressures above $100 \mathrm{~mm}$. $\mathrm{Hg}$ and were without evidence of congestive heart failure at the time the clearance tests were made. When there was any doubt of the ability to empty the bladder, the patient was catheterized at the beginning and end of the period of urine collection. The tests were made in the manner described in the preceding paper (6).

If there was any gross difference in the pathological condition of the two kidneys, the experiment was discarded. The number of glomeruli was estimated by Kunkel's (7) modification of Vimtrup's method. The kidney was perfused at $140 \mathrm{~mm}$. $\mathrm{Hg}$ pressure with a mixture of equal parts of 2.5 per. cent potassium ferrocyanide and ferric ammonium citrate, after washing out the blood with 0.9 per cent $\mathrm{NaCl}$. It was then cut in pieces, digested in 50 per cent $\mathrm{HCl}$ for 10 to 36 hours, washed in tap water, and allowed to stand in distilled water for 24 to 48 hours. When sufficiently digested, it was diluted to a suitable volume and thoroughly mixed. The number of glomeruli in $2 \mathrm{cc}$. aliquots was then counted on a ruled watch glass under a binocular microscope. In the majority of instances, the completeness of injection has been checked by histological sections, and the estimated number of glomeruli corrected for the proportion of apparently patent but uninjected glomeruli.

The use of such an estimate of the number of glomeruli involves several assumptions. It is assumed that the proportion of uninjected glomeruli is nearly the same throughout the kidney. Counts of injected and uninjected glomeruli in blocks taken from different parts of the kidney show 
little difference in the proportion of uninjected glomeruli. Any kidney in which a visible infarct was produced was discarded, or cut out and weighed and allowance made for it. It is assumed that the glomeruli are uniformly distributed throughout the suspension. Thorough mixing before sampling is essential. The variation in the counts of different aliquots is chiefly due to insufficient mixing. From 3 to 20 aliquots were counted, the standard deviation calculated and the estimate shown to be significant according to Fisher's (8) method of calculation. ${ }^{1}$ It is further assumed that the numbers of glomeruli in the two kidneys of the same individual are equal within about 10 per cent. This was shown for the rabbit by Hayman and Starr (9), for the human by Moore (10).

Estimations of the number of glomeruli in the normal human kidney vary from 560,000 to $5,700,000$ by different methods. By injection of iron salts and acid digestion Vimtrup (11) found 833,992 to $1,233,360$, and Moore 800,000 to $1,000,000$ with occasional values as low as 600,000 and as high as $1,200,000$. Our series includes 12 kidneys from persons without histological evidence of significant abnormalities in the glomeruli or. blood vessels. The counts ranged from 800,000 to $1,530,000$. The mean was $1,156,000$ and the standard deviation 191,266. This means that counts differing by more than twice the standard deviation, or below 773,000 , probably indicate a significant decrease in the number of glomeruli, while those differing by more than three times the standard deviation, or below 582,000 , certainly do.

Table I shows the comparison of creatinine and urea clearance tests with the estimated number of glomeruli in one kidney of 34 persons. We have followed Addis's classification of Bright's disease. In arteriosclerotic Bright's disease, decrease in clearances was associated with progressive reduction in the number of injected glomeruli. There were only 2 patients with active hemorrhagic Bright's disease and in one of these the estimate of the number of glomeruli is not significantly low. The other. showed about the same reduction in clearance tests and glomeruli as the sclerotic group. Since in both chronic hemorrhagic Bright's disease and arteriosclerotic Bright's disease the patency of the renal vessels is reduced to

${ }^{1}$ An example of the method of calculation. Hospital number 149-512. Weight of kidney before perfusion 163 grams; after perfusion 254 grams. Weight of pieces taken for histological section, 2 grams. After digestion, diluted to 16 liters. Counts on 2 cc. aliquots, 153, 155, 147, 189, 118, 148, 154, 96, 117, 111. Mean 138.8. Standard deviation 27. From these data, $t$, calculated by the method of Fisher, is $\mathbf{1 5 . 8 5}$ and the mean therefore significant. Estimate of total from mean 1,110,400. Correction for 2 grams taken for histological sections 8,812 . Corrected estimate of count $1,119,212$. In a count of 1,075 glomeruli from 3 blocks in sections so spaced that no glomerulus was counted twice, 1,052 contained injection mass, 23 apparently patent glomeruli did not. Correction for uninjected patent glomeruli 24,465. Final estimate of patent glomeruli 1,143,400. 
TABLE I

Relation of creatinine and urea clearance tests and the number of glomeruli in one kidney

\begin{tabular}{|c|c|c|c|c|c|c|c|}
\hline $\begin{array}{c}\text { Case } \\
\text { num- } \\
\text { ber }\end{array}$ & $\begin{array}{c}\text { Hospital } \\
\text { number }\end{array}$ & Sex & Age & Diagnosis & $\begin{array}{l}\text { Creatinine } \\
\text { clearance }\end{array}$ & $\begin{array}{l}\text { Urea } \\
\text { clear- } \\
\text { ance }\end{array}$ & $\begin{array}{l}\text { Glomeruli } \\
\text { in one } \\
\text { kidney }\end{array}$ \\
\hline & & & years & & $\begin{array}{l}\text { cc. per } \\
\text { minute }\end{array}$ & $\begin{array}{l}\text { cc. per } \\
\text { minute }\end{array}$ & \\
\hline 1 & $143-651$ & F & 34 & Miliary tuberculosis & 145 & $40.6^{*}$ & $1,260,000$ \\
\hline 2 & $149-586$ & F & 23 & Miliary tuberculosis & 204 & 112.0 & $1,230,000$ \\
\hline 3 & $145-915$ & $\mathrm{~F}$ & 15 & Tuberculous meningitis & 129 & $66.7^{*}$ & $1,064,000$ \\
\hline 4 & $136-525$ & $\mathbf{M}$ & 28 & Diabetes insipidus & 104 & 39.0 & $1,288,000$ \\
\hline 5 & $147-691$ & $\mathbf{M}$ & 36 & Miliary tuberculosis & 108 & $36.0^{*}$ & 800,000 \\
\hline 6 & $146-212$ & $\mathbf{M}$ & 33 & Tuberculous meningitis & 94 & 51.0 & 896,000 \\
\hline 7 & $145-644$ & $\mathbf{M}$ & 27 & Pneumonia & 231 & $76.0^{*}$ & $1,250,000$ \\
\hline 8 & $142-828$ & $\mathbf{M}$ & 36 & Pneumonia & 151 & $62.0^{*}$ & $1,037,000$ \\
\hline 9 & $142-587$ & $\mathbf{M}$ & 26 & Pneumonia & 145 & $26.0^{*}$ & $1,336,000$ \\
\hline 10 & $150-738$ & $\mathbf{M}$ & 51 & Pneumonia & 38 & $8.3^{*}$ & $1,530,000$ \\
\hline 11 & $143-756$ & $\mathbf{M}$ & 36 & Pneumonia & 23 & 9.5 & $1,250,000$ \\
\hline 12 & $146-484$ & $\mathbf{M}$ & 75 & $\begin{array}{l}\text { Carcinoma of prostate and ar- } \\
\text { teriosclerotic Bright's disease }\end{array}$ & 81 & $28.7^{*}$ & $1,056,000$ \\
\hline 13 & $149-816$ & $\mathrm{~F}$ & 67 & $\begin{array}{l}\text { Carcinoma of stomach and ar- } \\
\text { teriosclerotic Bright's disease }\end{array}$ & 44 & $11.8^{*}$ & 402,000 \\
\hline 14 & $144-079$ & F & 38 & Arteriosclerotic Bright's disease & 35 & $11.2^{*}$ & 490,000 \\
\hline 15 & $145-997$ & $\mathbf{M}$ & 29 & Arteriosclerotic Bright's disease & 47 & $27.0^{*}$ & 390,000 \\
\hline 16 & $142-324$ & $\mathbf{M}$ & 55 & Arteriosclerotic Bright's disease & 32 & $29.0^{*}$ & 474,000 \\
\hline 17 & $149-143$ & $\mathbf{M}$ & 54 & Arteriosclerotic Bright's disease & 30 & & 344,000 \\
\hline 18 & $143-018$ & $\mathrm{~F}$ & 25 & Arteriosclerotic Bright's disease & 27 & $12.3^{*}$ & 413,000 \\
\hline 19 & $149-634$ & $\mathbf{M}$ & 44 & Arteriosclerotic Bright's disease & 18 & 13.0 & 422,000 \\
\hline 20 & $149-237$ & $\mathbf{M}$ & 58 & Arteriosclerotic Bright's disease & 15 & 5.0 & 240,000 \\
\hline 21 & $134-806$ & $\mathrm{~F}$ & 32 & Arteriosclerotic Bright's disease & 7 & $4.0^{*}$ & 359,000 \\
\hline 22 & $91-504$ & F & 43 & Arteriosclerotic Bright's disease & 3 & $3.6^{*}$ & 275,000 \\
\hline 23 & $146-741$ & $\mathbf{M}$ & 56 & Arteriosclerotic Bright's disease & 3 & $0.3^{*}$ & 168,000 \\
\hline 24 & $147-168$ & F & 40 & Arteriosclerotic Bright's disease & 2 & $1.7^{*}$ & 192,000 \\
\hline 25 & $145-306$ & $\mathrm{~F}$ & 43 & Arteriosclerotic Bright's disease & 1 & & 156,000 \\
\hline 26 & $141-832$ & $\mathbf{M}$ & 47 & Arteriosclerotic Bright's disease & 0.6 & $0.2^{*}$ & 195,000 \\
\hline 27 & $149-512$ & $\mathbf{M}$ & 21 & $\begin{array}{l}\text { Focal hemorrhagic Bright's dis- } \\
\text { ease }\end{array}$ & 126 & $39.0^{*}$ & $1,143,000$ \\
\hline 28 & $141-891$ & F & 19 & $\begin{array}{l}\text { Acute hemorrhagic Bright's dis- } \\
\text { ease }\end{array}$ & 3 & $2.5^{*}$ & 819,000 \\
\hline 29 & $142-730$ & $\mathbf{M}$ & 36 & $\begin{array}{l}\text { Active hemorrhagic Bright's } \\
\text { disease }\end{array}$ & 29 & $13.8^{*}$ & 746,000 \\
\hline 30 & $151-508$ & $\mathrm{~F}$ & 27 & $\begin{array}{l}\text { Active hemorrhagic Bright's } \\
\text { disease }\end{array}$ & 12 & $5.5^{*}$ & 170,000 \\
\hline 31 & $144-740$ & $\mathbf{M}$ & 50 & $\begin{array}{l}\text { Pyelonephritis with multiple } \\
\text { abscesses and arteriosclerotic } \\
\text { Bright's disease }\end{array}$ & 2 & $1.4^{*}$ & 393,000 \\
\hline 32 & $144-053$ & $\mathbf{M}$ & 71 & $\begin{array}{l}\text { Hypertrophied prostate and } \\
\text { pyelonephritis with multiple } \\
\text { abscesses }\end{array}$ & 5 & 3.5 & 490,000 \\
\hline 33 & $147-594$ & F & 34 & $\begin{array}{l}\text { Pyelonephritis and B. coli sep- } \\
\text { ticemia }\end{array}$ & 9 & $6.9^{*}$ & $1,330,000$ \\
\hline 34 & $149-077$ & F & 52 & $\begin{array}{l}\text { Carcinoma of pancreas and bile } \\
\text { nephrosis }\end{array}$ & 3 & & 645,000 \\
\hline
\end{tabular}

\footnotetext{
* Standard clearance.
} 
about the same degree (12), and since not only is the final clinical picture often very similar, but even the pathological distinction at times difficult, it seems that in both groups the reduction in clearances is probably due to reduction in number of glomeruli.

In patients with acute nephritis who show decreased clearance values with return toward normal during convalescence it seems reasonable to suppose that certain glomeruli have been rendered temporarily functionless by inflammation, but that the process has not gone on to destruction, so that recovery can take place. The one patient in the series with acute hemorrhagic nephritis had a very low clearance, but a normal number of glomeruli. The injection method of estimating glomeruli does not, of course, distinguish between normal and abnormal glomeruli since any whose capillaries are sufficiently patent to be injected at the pressure used must be counted. Sections of the other kidney from this patient showed degenerative or inflammatory changes in nearly every glomerulus.

Möller, McIntosh and Van Slyke attribute decrease in the volume of blood cleared of urea per. minute in pathological conditions to one of two causes : either a decrease in the volume of blood passing through the kidneys, or a decrease in the proportion of its urea removed during the passage. In cardiac decompensation, glomerular. nephritis and arteriolar sclerosis diminished flow seems certain. Whether a decrease in the proportion of urea removed from the blood also occurs they felt there was at present no basis to surmise. Holten and Rehberg on the other hand believe from comparison of creatinine and urea excretion rates, that the proportion of urea removed is quite variable, the variation being due to back diffusion of different amounts of urea from concentrated solution in the lumen of the tubule. They believe that a certain amount of back diffusion takes place normally, and that this may be increased by tubular damage. The small group in Table I associated with general or urogenital infection lends support to this conception, but would extend it to include back diffusion of creatinine as well at least in pathological conditions. This group showed low clearances and yet a normal number of glomeruli which in histological section did not appear significantly abnormal.

While it is of course possible that the volume of glomerular filtrate may have been reduced in these cases, it seems more probable that the cause of the low clearance values lies in toxic damage to tubule cells so that they are no longer. able to resist back diffusion of urea or creatinine from the lumen of the tubule into the peritubular capillaries. This is illustrated in the group of patients with pneumonia. Cases 7 and 8 had normal concentrations of blood urea nitrogen and creatinine and normal clearances. Case 9 had a normal blood creatinine and creatinine clearance, but an elevated blood urea nitrogen and a reduced urea clearance. This we would interpret as indicating sufficient damage to tubules to permit an increase in the normal back diffusion of urea, but insufficient to allow 
appreciable back diffusion of the normally more concentrated creatinine. Cases 10 and 11 had increase of both urea nitrogen and creatinine, and a reduction in both clearances, but a normal number of glomeruli and adequate blood pressure. Here it seems probable that tubule cells were sufficiently damaged to permit back diffusion of both urea and creatinine. We have no explanation to offer for the presence of this type of damage in some pneumonia patients and not in others.

If this interpretation be correct, its bearing on the significance of clearance tests is obvious. They may be used as a measure of the "amount" of functioning renal tissue only in the absence of sepsis or toxic damage to tubules. When these are present, clearance tests indicate the manner in which the kidney eliminates the test substance, but how much of a reduced clearance is due to reduction in amount of functioning renal mass and how much to abnormal behavior of that mass it is impossible to say.

Additional evidence that variation in the proportion of urea removed from the blood occurs is indicated by the effect of drugs (Table II). After

TABLE II

Effect of drugs on creatinine and urea clearance tests

\begin{tabular}{|c|c|c|c|c|c|c|}
\hline \multirow[t]{2}{*}{ Name } & \multirow[t]{2}{*}{ Drug } & \multirow{2}{*}{$\begin{array}{c}\begin{array}{c}\text { Urine } \\
\text { volume }\end{array} \\
\begin{array}{c}\text { cc. per } \\
\text { minute }\end{array}\end{array}$} & \multicolumn{2}{|c|}{$\begin{array}{l}\text { Creatine } \\
\text { clearance }\end{array}$} & \multicolumn{2}{|c|}{ Urea clearance } \\
\hline & & & $\begin{array}{l}c c . \text { per } \\
\text { minute }\end{array}$ & $\begin{array}{l}\text { Per cent } \\
\text { average } \\
\text { normal }\end{array}$ & $\begin{array}{l}c c \text {. per } \\
\text { minute }\end{array}$ & $\begin{array}{l}\text { Per cent } \\
\text { average } \\
\text { normal }\end{array}$ \\
\hline B & $\begin{array}{l}\text { Control-1st hour } \ldots \ldots \ldots \ldots \ldots \\
\text { Control-2nd hour } \ldots \ldots \ldots \ldots\end{array}$ & $\begin{array}{l}4.26 \\
4.23\end{array}$ & $\begin{array}{l}169 \\
164\end{array}$ & $\begin{array}{l}114 \\
111\end{array}$ & $\begin{array}{l}75.0 \\
77.0\end{array}$ & $\begin{array}{l}100 \\
103\end{array}$ \\
\hline $\mathrm{H}$ & $\begin{array}{l}\text { Before pituitrin } \ldots \ldots \ldots \ldots \ldots \ldots \\
\text { After pituitrin } \ldots \ldots \ldots \ldots \ldots\end{array}$ & $\begin{array}{r}11.33 \\
.66\end{array}$ & $\begin{array}{l}138 \\
113\end{array}$ & $\begin{array}{l}93 \\
76\end{array}$ & $\begin{array}{l}90.0 \\
26.85^{*}\end{array}$ & $\begin{array}{r}120 \\
50\end{array}$ \\
\hline C & $\begin{array}{l}\text { Before pituitrin } \ldots \ldots \ldots \ldots \ldots \ldots \\
\text { After pituitrin } \ldots \ldots \ldots \ldots \ldots \ldots\end{array}$ & $\begin{array}{l}8.75 \\
3.17\end{array}$ & $\begin{array}{l}86 \\
71\end{array}$ & $\begin{array}{l}58 \\
48\end{array}$ & $\begin{array}{l}49.5 \\
24.9\end{array}$ & $\begin{array}{l}66 \\
33\end{array}$ \\
\hline $\mathbf{S}$ & $\begin{array}{l}\text { Before adrenalin } \ldots \ldots \ldots \ldots \ldots \\
\text { After adrenalin........... }\end{array}$ & $\begin{array}{l}7.70 \\
3.75\end{array}$ & $\begin{array}{l}196 \\
139\end{array}$ & $\begin{array}{r}132 \\
94\end{array}$ & $\begin{array}{l}75.0 \\
57.5\end{array}$ & $\begin{array}{r}100 \\
77\end{array}$ \\
\hline B & $\begin{array}{l}\text { Before morphine } \ldots \ldots \ldots \ldots \ldots \\
\text { After morphine } \ldots \ldots \ldots \ldots \ldots\end{array}$ & $\begin{array}{l}4.80 \\
2.75\end{array}$ & $\begin{array}{l}181 \\
143\end{array}$ & $\begin{array}{r}122 \\
97\end{array}$ & $\begin{array}{l}87.0 \\
82.7\end{array}$ & $\begin{array}{l}116 \\
110\end{array}$ \\
\hline $\mathrm{L}$ & $\begin{array}{l}\text { Before caffeine } \ldots \ldots \ldots \ldots \ldots \ldots \\
\text { After caffeine } \ldots \ldots \ldots \ldots \ldots \ldots\end{array}$ & $\begin{array}{l}1.91 \\
5.68\end{array}$ & $\begin{array}{l}126 \\
158\end{array}$ & $\begin{array}{r}85 \\
107\end{array}$ & $\begin{array}{l}32.7^{*} \\
73.5\end{array}$ & $\begin{array}{l}61 \\
98\end{array}$ \\
\hline
\end{tabular}

* Standard clearance.

the administration of pituitrin, the excretion of urea is diminished relatively more than that of creatinine, while after adrenalin and morphine it is decreased less. After caffeine, there is a greater increase in urea clearance than in creatinine clearance. These experiments were all done in the 
morning when MacKay (13) has shown that variations in clearances are least. Fluid intake was constant, the drugs given hypodermically five minutes before the end of the control hour. While there is nothing in the simple comparison of the two tests to indicate that it is the proportion of urea removed from the blood that varies, rather than creatinine, the relatively constant rate of creatinine excretion, independent of urine volume, and the variation in the rate of urea excretion with urine volume make it seem more probable that there is greater variation in the proportion of urea removed than of creatinine. If the creatinine clearance represents the volume of glomerular filtrate, it must indicate that variations in the volume of filtrate are of less importance in determining the final volume of urine than are differences in the volume of fluid reabsorbed by the tubules.

\section{SUM MARY}

The results of creatinine and urea clearance tests of kidney function have been compared with estimates of the number of glomeruli in one kidney after postmortem injection. In arteriosclerotic Bright's disease, and probably in chronic hemorrhagic Bright's disease, reduction in clearance tests is associated with decrease in the number of injected glomeruli. In pneumonia and pyelonephritis, the clearances may be greatly reduced in the presence of a normal number of glomeruli. It is suggested that this may be due to back diffusion of the test substance through damaged tubule cells.

We are indelsted to Dr. Allan R. Moritz for the histological examination of the kidneys and for the differential counts of injected and uninjected glomeruli.

\section{BIBLIOGRAPHY}

1. Möller, E., McIntosh, J. F., and Van Slyke, D. D., J. Clin. Invest., 1928, vi, 427. Studies of Urea Excretion. II. Relationship Between Urine Volume and the Rate of Urea Excretion by Normal Adults.

2. Van Slyke, D. D., Stillman, E., Möller, E., Ehrich, W., McIntosh, J. F., Leiter, L., MacKay, E. M., Hannon, R. R., Moore, N. S., and Johnston, C., Medicine, 1930, ix, 257. Observations on the Courses of Different Types of Bright's Disease, and on the Resultant Changes in Renal Anatomy.

3. Addis, T., and Oliver, J., The Renal Lesion in Bright's Disease. Paul B. Hoeber, Inc., New York, 1931.

4. Holten, C., and Rehberg, P. B., Acta med. Scandinav., 1931, 1xxiv, 479. Studies on the Pathological Function of the Kidneys in Renal Disease, Especially Bright's Disease. I.

5. Shannon, J. A., Jolliffe, N., and Smith, H. W., Am. J. Physiol., 1932, cii, 534. The Excretion of Urine in the Dog. VI. The Filtration and Secretion of Exogenous Creatinine.

6. Hayman, J. M., Jr., Halsted, J. A., and Seyler, L. E., J. Clin. Invest., 1933, xii, 861. A Comparison of the Creatinine and Urea Clearance Tests of Kidney Function. 
7. Kunkel, P. A., Jr., Bull. Johns Hopkins Hosp., 1930, xlvii, 285. The Number and Size of the Glomeruli in the Kidney of Several Mammals.

8. Fisher, R. A., Statistical Methods for Research Workers. Oliver and Boyd, Edinburgh, 1928, 2d ed.

9. Hayman, J. M., Jr., and Starr, I., Jr., J. Exper. Med., 1925, xlii, 641. Experiments on the Glomerular Distribution of Blood in the Mammalian Kidney.

10. Moore, R. A., Anat. Rec., 1931, xlviii, 153. The Total Number of Glomeruli in the Normal Human Kidney.

11. Vimtrup, B., Am. J. Anat., 1928, xli, 123. On the Number, Shape, Structure and Surface Area of the Glomeruli in the Kidneys of Man and Mammals.

12. Hayman, J. M., Jr., J. Clin. Invest., 1929, viii, 89. Experiments on the Patency of the Blood Vessels of Nephritic Kidneys Obtained at Autopsy.

13. MacKay, E. M., J. Clin. Invest., 1929, vi, 505. Studies of Urea Excretion. V. The Diurnal Variation of Urea Excretion in Normal Individuals and Patients with Bright's Disease. 